\title{
Seismicity of Kerala: An update
}

\author{
Biju John, A Rajan Babu, DS Subrahmanyam \\ Yogendra Singh, KS Divyalakshmi \\ and S Nelliat \\ National Institute of Rock Mechanics \\ Kolar Gold Fields, India \\ b_johnp@yahoo.co.in
}

\author{
E. Praseeda, Pijush Samui and GP Ganapathy \\ Vellore Institute of Technology University \\ Vellore, India
}

\begin{abstract}
The earthquake catalogue of the Kerala State indicates that the central part of the state (WadakkancheriTrissur and Idukki -Kottayam- Pala) is witnessing repeated seismicity. Though lineaments of all directions are identified in Kerala, some NW-SE trending structures are identified as neotectonically active and some of these NW-SE trending structures are even the source of recent seismicity. Some of the fault related geological studies in Peninsular India (Wadakkancheri, Periyar and Thenmala faults) identified that the region is responding to compressive tectonic regime. The slickensides from these faults indicate the recent movements are consistent with the present tectonic stress regime. Though the geological observations and seismological data indicate northeast directed stress regime, the in-situ stress measurement carried out at northern side of the study area shows local perturbation in maximum horizontal stress. Analysis of available seismic data of the region suggest that the seismic source at Idukki-Pala is indicating some recurrence pattern for moderate earthquakes and are spatially located close to the southeastern end of Periyar fault. The seismicity in the Wadakkancheri-Trissur, on the other hand, falls in the northwestern end of Periyar fault. It is also to be noted that the earthquakes in central Kerala were occurring as doublets. Thus, the estimation of earthquake potential of these regions through a proper integration of different disciplines and techniques is the need of the hour.
\end{abstract}

Keywords-Seismicity; horizontal stress; neotectonic; recurrence interval

\section{I.INTRODUCTION}

The Kerala state, part of Stable Continental Region (SCR) lies in seismic zone III [1], where the maximum expected MM scale intensity would correspond to VIII $(\mathrm{M} \sim 5.5)$. Despite the low strain rates, the SCR seismicity includes damaging earthquakes, and poses substantial overall hazard because of the availability of critically loaded faults distributed over a large area. The long interseismic intervals and elapsed times, characteristic of SCR seismicity, are generally leading to a false sense of security resulting in a general lack of earthquake preparedness. It is generally understood that the seismic sources in the SCR's are related to preexisting faults/zones of weakness [e.g. 2,3,4]. The examples of such events include damaging earthquakes at Tennant Creek (Australia, 1988), New Madrid (USA, 1811-1812), the Rann of Kachchh and Assam (India, 1819 and 2001) and Ungava (Canada, 1989). But there are gaps in our present understanding of the locations of potential faults and their pattern of behaviour in space and time. The long repeat times for earthquakes in slowly deforming regions can potentially lead to local populations being relatively unprepared for these unexpected events. For example, the 2001 Mw7.6 Bhuj (Gujarat) earthquake in NW India caused over 20,000 deaths in a relatively sparsely populated area. Therefore, it is important to identify all the potential discrete structures within the region, which have not ruptured for a long time. From this point of view, it is imperative to study historically active zones as a first step in hazard assessment.

\section{II.ACTIVE DEFORMATION OF THE INDIAN SUBCONTINENT}

Southern Peninsular India consists of a union of high grade Precambrian crystalline terrains which are separated by shear zones. Various thermo-tectonic events are identified in these terrains and shear zones much earlier [e.g. 5,6]. The youngest thermotectonic event in this region was occurred around 550 $\mathrm{Ma}$ [7]. These thermo-tectonic events were occurred well before the split of Gondwana around $120 \mathrm{Ma}$. During the northward movement of Indian land mass the entire region experienced tension till it collided with Eurasian plate around $40 \mathrm{Ma}$ [8]. The continued northward push of the Indian continent towards the Eurasian plate resulted in the formation of Himlaya and changed the tensional regime of Indian plate into compression [9].

The largest earthquake occurred in the Indian subcontinent in the modern instrumental period is the $2001 \mathrm{Mw} 7.6$ Bhuj (Gujarat) thrust-faulting earthquake in northwest India $[10,11,12]$. Several authors $[13,14,15]$ have noted that many Indian earthquakes are associated with preexisting structural weakness, such as an abandoned rift in the case of the Bhuj and Rann of Kachchh events. Evidences are also found that the 1993 Killari event occurred as fault reactivation of Precambrian crust [16]. A number of recent earthquakes occurred along the ENE-WSW trending Narmada-Son Lineament proved the reactivation of the Precambrian tectonic feature $[17,18,19]$.

\section{III.MAJOR GEOLOGICAL STRUCTURES IN KERALA}

Palghat Cauvery and Achankovil are major shear systems in peninsular India (Fig. 1). Apart from these earlier studies also identified four deformation phases in the basement rocks of Kerala [20]. Though lineaments of all directions are identified in Kerala, some NW-SE trending structures are identified as neotectonically active and some of these NW-SE trending structures are even the source of recent seismicity. 


\section{IV.OBSERVATION ON NEOTECTONISM IN PALGHAT-CAUVEY SHEAR ZONE}

The Bharathapuzha River sourced at the Western Ghat and its tributaries constitute the drainage network in the PalghatCauvery shear zone. At Desamangalam, a NW-SE trending fault is identified as influenced the main course of Bharathapuzha [21]. This fault follows an elongated hill ridges and created a waterfall with a board upstream valley and a narrow downstream valley [22]. The isoseismal elongation of 1994 earthquake is also coinciding with this fault [21]. Detailed morphological, textural and mineralogical studies of this fault indicate episodic nature of fault growth [22] where the major displacement is dated at around $430 \mathrm{ka}$ [23].

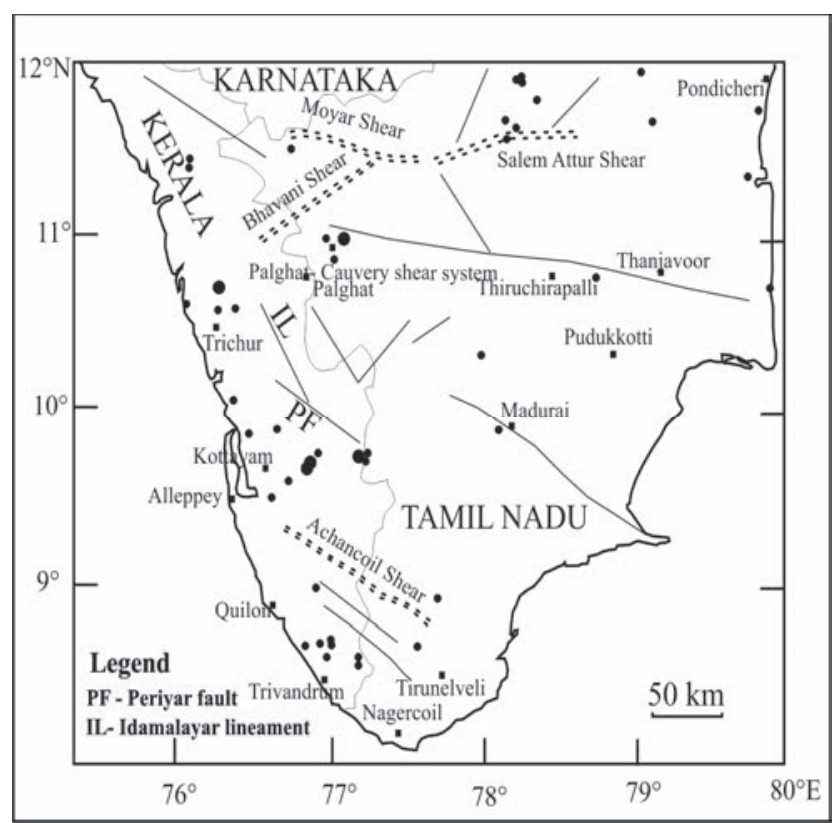

Fig. 1 Seismotectonic map of South India adopted from SEISAT [24].

In central Kerala, Periyar lineament is identified as fault along which the river Periyar is flowing [24]. Drainage system of the area is also controlled by the NW-SE trending lineaments corresponding to Periyar lineament that enters into Palghat-Cauvery shear zone. Singh et al., [25] identified that the continuity of this fault as segmented lineaments in the northwestern end and have induced drainage anomalies in the area. Their studies identified subtle landform modifications induced by ongoing tectonic adjustments in the area. Southeastern end of this lineament is associated with seismicity (e.g. 1988 Idukki $M=4.5$ earthquake). Signature of the NW-SE trending lineament is traced as faults at several locations along its trace [25].

Another recent study evaluated the Thenmala fault as a prominent structure in the Achankovil shear system which is demarcated by the straight course of Kallada and Chendurni rivers [26]. At the southeastern end within the hill ranges it shows discontinuous features. Field observations in the plain area around the Thenmala fault identified faults in crystalline rocks at several locations [26]. A wide range of faulting, characteristics to brittle deformation, are observed in different exposures.

\section{V.SEISMICITY AND RECURRENCE PATTERN IN CENTRAL KERALA}

The seismic potential of Indian peninsula, except for Kutch region, can be considered as below moderate, with very rare occurrence of earthquakes of magnitude 6.0 or above $[14,27]$. The occurrences of seismic events in different parts of the peninsula are of isolated nature and appear to be associated with weak zones [28,29].

The Kerala state is also witnessing seismicity since historic time. It is noted that several of the Kerala tremors are spatially associated with some of the major drainage basins and associated faults [30]. The low-level seismicity in the vicinity of the Idukki is an example of earthquakes triggered by the effect of increased pore pressure in the fault zone [31]. The earthquake catalogue of the region indicates that the central part of the state (Wadakkancheri-Trissur and Idukki Kottayam- Pala) is witnessing recent seismicity (Fg.2). Around Thiruvananthapuram another cluster of microearthquakes are also noticed.

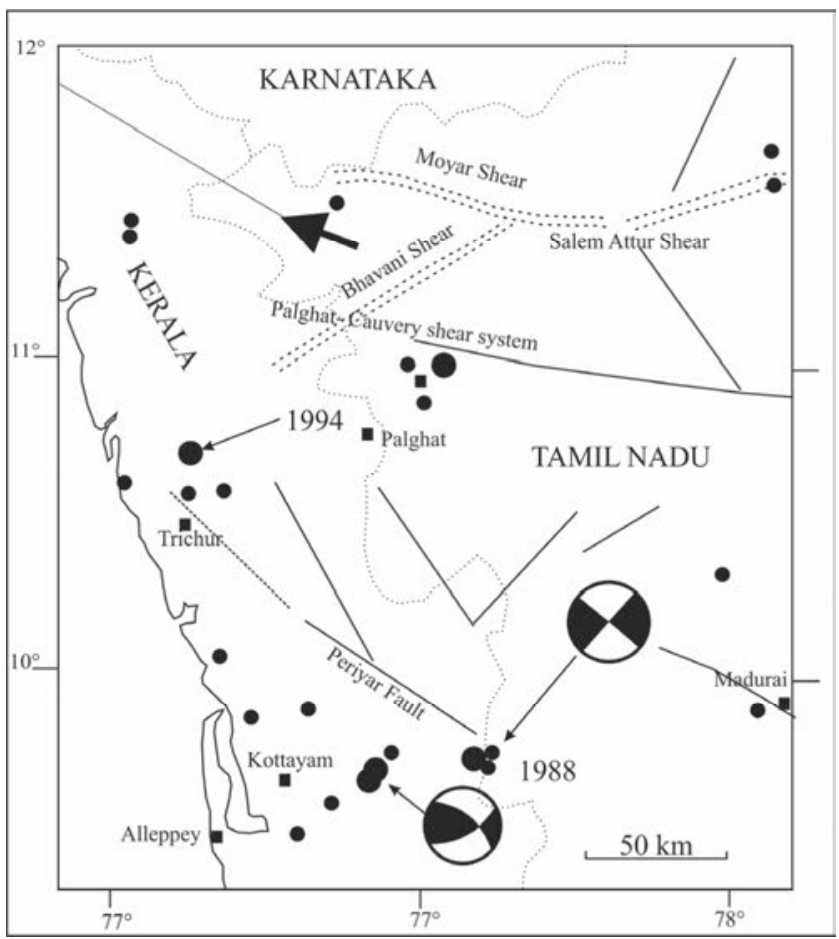

Fig. 1 Seismicity of central Kerala and fault plane solutions. The dark thick arrow indicate the horizontal stress direction at Pykara, Tamilnadu.

The historical information indicates that the central Kerala witnessed repeated occurrences of doublets in Idukki-PalaKottayam region [31]. The available information indicates a doublet event in 1953 (February 25th and March 21st) separated by an interval of twenty one days, located to the south of the epicentres of the 2000-2001 (December 12th and January 7 th) earthquakes. The earthquake sequence of 20002001 Erattupetta/Pala had been the most recent significant events in this region (Bhattacharya and Dattatrayam, 2002). These earthquake doublets had occurred within 26 days. Events of the year 1856 (August 11th and August 25th) are particularly noteworthy and the two events separated by an interval of 14 days. 
On the southeastern terminus of Periyar fault/lineament, an earthquake of M 4.5 was reported on 09.06.1988 [33], which was followed by several aftershocks [32]. This earthquake was felt in about $50 \mathrm{~km}$ radius, and caused damage to buildings in the epicentral area and was assigned a maximum intensity VI. Mishra et al. [34] based on gravity studies, identified a shallow structure corresponding to Periyar Fault in that area. The composite fault plane solution suggests its association with Periyar Fault [35].

Since 1989 the region Wadakkancheri- Trissur is experiencing seismicity. The biggest of them (M 4.3) is located at $10.75^{\circ} \mathrm{N}$ and $76.25^{\circ} \mathrm{E}$ [36], and its isoseismal elongation is spatially coincide with the Desamangalam Fault [37]. This earthquake made widespread minor damages to houses around the epicentral area (intensity V). Subsequent mild activity was reported further south of the 1994 event [31]. During April-July 2012, another swarm of earthquake events occurred southeast of Wadakkancheri. The biggest event $\mathrm{M}=3.8$ occurred on 19.07.2012 near Tannikulam. Spatially this region is in the northwestern terminus of the Periyar lineament/fault.

It should be noted that these two source zones viz., Idukiki-Pala-Kottayam and Wadakkancheri-Trissur spacially close to the either end of NW-SE trending Periyar fault/lineament.

\section{VI.THE REGIONAL STRESS CONDITIONS}

The current stress pattern in Indian subcontinent is identified as compression in a NNE-SSW direction $[9,38]$. Reverse faults striking NW-SE to WNW-ESE are favorable for reactivation [39].

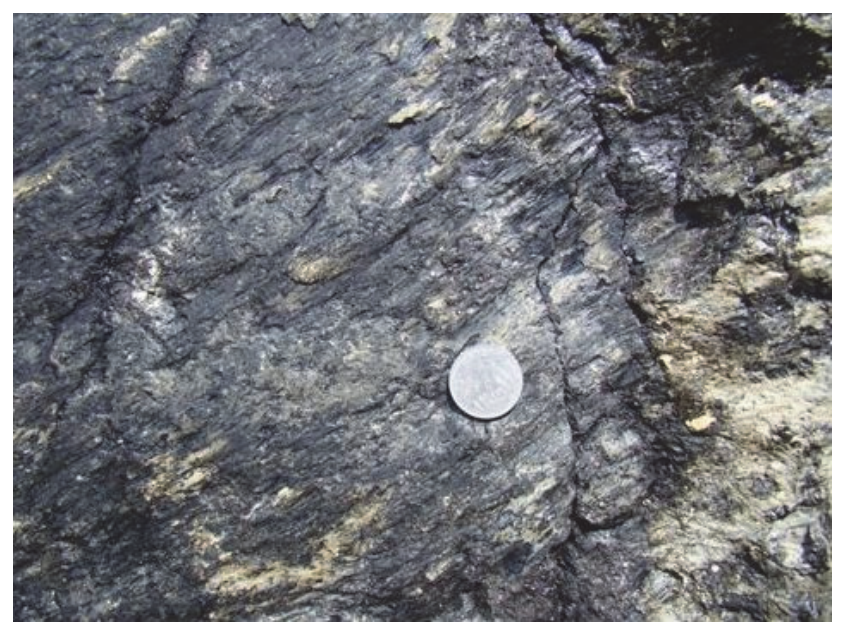

Fig. 3. Slickensides, indication north directed movement across the fault plane observed in the 1994 earthquake epicentral zone referred in figure 2.

Studies also indicate that the stress induced by topography and crustal inhomogeneities below south of $12^{\circ} \mathrm{N}$ also favors reverse faulting mechanism for the region [40].

Preliminary analysis of GPS data suggested internal compression of India as $\leq 2 \mathrm{~mm} / \mathrm{yr}$ [41]. Later data from more dense GPS network was evaluated and suggested a similar rate of $2 \pm 1 \mathrm{~mm} / \mathrm{yr}$ of north-south shortening [42].
Some of the fault related geological studies in Peninsular India (Wadakkancheri, Periyar and Thenmala faults) identified that the region is responding to compressive tectonic regime $[22,25,26]$. The slickensides from these faults indicate the recent movements are consistent with the present tectonic stress regime. The in-situ stress measurement carried out at Pykara, Tamilnadu shows the stress perturbation in the north directed maximum horizontal stress in the region.

\section{VII.DISCUSSION}

The seismicity in Kerala shows a noticeable increase during the recent times. They are mostly associated with the NW-SE trending structural features which are considered as favourable orientation for movement in the present stress regime. The earthquakes in central Kerala region exhibits spatial association with NW-SE trending Periyar lineament/fault. The earthquake in the Idukki-Pala-Kottayam indicate repeated occurrence of doublets.

Composite fault plane solutions of the 2000-2001 events show a NW-SE and NE-SW trending nodal planes with a dominant strike slip component [33]. The Idukki event that occurred close to the southeastern end of Periyar fault/lineament indicate a NW-SE and NE-SW trending strike slip fault [35]. Wadakkancheri-Trissur region is another area showing recent seismicity which is falling on the northwestern end of Periyar lineament.

This spatial relation of these two source zones is a matter of concern in a compressive tectonic regime as the orientation of Periyar fault (NW-SE) is considered as one favorable for reactivation. Thus, the estimation of earthquake potential of these regions through a proper integration of different disciplines and techniques is the need of the hour. As a basic requirement for hazard assessment, a proper seismic network should be designed to detect the nucleation and/or remote triggering and/or migratory nature, if any. By employing a state of art GPS Geodetic network, the movement across the fault system can be detected so as to estimate the strain buildup.

\section{ACKNOWLEDGMENT}

We express our sincere gratitude to the SERB division of the Department of Science and Technology for funding (SR/S4/ES-434/2009) this study. The investigators thank Dr V. Venkateswarlu, Director, NIRM for his encouragement, support and facilities. BJ, YS, PS, GPG thank VIT University for permission to publish this work.

\section{REFERENCES}

[1] I.S 1893-2002, Criteria for earthquake resistance design of structures, Bureau of Indian Standards (BIS) New Delhi, 2002.

[2] L.R. Sykes, Intraplate seismicity, reactivation of preexisting zones of weakness, alkaline magmatism and other tectonism postdating continental fragmentation. Rev. Geophys. Physics, vol. 16, pp. 621$628,1978$.

[3] A.C. Johnston and L.R. Kanter, Earthquakes in stable continental crust, Scientific American, vol. 262, pp. 68-75, 1990.

[4] S.M. Schulte and W.D. Mooney, An updated global earthquake catalogue for stable continental regions: Reassessing the correlation with ancient rifts, Geophys. J. Int. vol. 161 pp. 707-721, 2005.

[5] M. Santosh, S. Yokoyama, S. Biju-Sekhar, and J.J.W. Rogers, Multiple tectonothermal vents in the granulite block of Southern India revealed 
from EPMA dating: implication on the history of supercontinents, Gondwana Research vol. 6, pp. 29-63, 2003.

[6] J. G. Ghosh, M.J. de Wit and R.E. Zartman, Age and tectonic evolution of Neoproterozoic ductile shear zones in the Southern Granulite Terrain of India, with implications for Gondwana studies; Tectonics, vol. 23 pp. 1-38, 2004.

[7] K. Soman, K.G., Tara, M,M. Arakelyants, and V.N. Golubyev, Mineral ages of pegmatites from Palghat gap region in Kerala and their tectonic significance. L. Geol. Soc. India vol. 35, pp. 82-86, 1990.

[8] P. Molnar, and P. Tapponnier, Collision between India and Eurasia. Scientific American, vol. 236, pp. 30-41, 1977.

[9] T.N. Goud, S.V. Srirama Rao, and V.K. Gour, Tectonic stress field in the Indian subcontinent. J. Geophys. Res. vol. 97, pp. 11,879-11,888, 1992.

[10] S. G. Wesnousky, L. Seeber, T. K. Rockwell, V. Thakur, R. Briggs, S. Kumar, and D. Ragona, Eight days in Bhuj: Field report bearing on surface rupture and genesis of the 26 January 2001 Republic Day earthquake of India, Seismol. Res. Lett., vol.72, pp. 514-524, 2001

[11] M. Antolik and D. S. Dreger, Rupture process of the 26 January 2001 Mw 7.6 Bhuj, India, earthquake from teleseismic broadband data, Bull. Seismol. Soc. Am., vol. 93, pp.1235-1248, 2003.

[12] D. A. Schmidt and R. Burgmann, InSAR constraints on the source parameters of the 2001 Bhuj earthquake, Geophys. Res. Lett., vol. 33, L02315, doi:10.1029/2005GL025109, 2006.

[13] B. R. Rao, Historical seismicity and deformation rates in the Indian peninsular shield, J. Seismol., vol. 4, pp. 247-258, 2000.

[14] C. P. Rajendran, Using geological data for earthquake studies: A perspective from peninsular India, Current Science, vol. 79, pp. 1251$1258,2000$.

[15] Copley, S. Mitra, R. Alastair Sloan, S. Gaonkar, and K. Reynolds, Active faulting in apparently stable peninsular India: Rift inversion and a Holocene-age great earthquake on the Tapti Fault, J. Geophys. Res. Solid Earth, vol. 119, doi:10.1002/2014JB011294, 2014.

[16] C.P. Rajendran, K. Rajendran, and B. John, The 1993 Killari (Latur), Central India earthquake : An example of fault reactivation in the Precambrian crust, Geology, vol. 24, pp. 651-654, 1996.

[17] W. D. West, The line of Narmada-Son valley, Curr. Sci., vol. 31, pp.143-144, 1962

[18] V. D. Choubey, Narmada-Son lineament, India, Nature, vol. 232, pp. 38-40, 1971.

[19] S. K. Biswas, Rift basins in western margin of India and their hydrocarbon prospects with special reference to Kutch basin, Bull. Am. Assoc. Petrol., vol. 66, pp. 1497-1513, 1982.

[20] S. Sinha-Roy, Structural evolution of Precambrian crystalline rocks in parts of Trivandrum and Quilon district, Kerala, Prof. paper No. 7 CESS. 25p, 1980

[21] B John and C P Rajendran Geomorphic indicators of Neotectonism from the Precambrian terrain of Peninsular India: a study from the Bharathapuzha Basin, Kerala, J. Geol. Soc. India, vol. 71 pp. 827-840, 2008 .

[22] B. John, and C.P. Rajendran, Evidence of episodic brittle faulting in the cratonic part of the Peninsular India and its implications for seismic hazard in slow deforming regions Tectonophysics, vol. 471, pp. 240252, 2009.

[23] T.K.G. Rao, C.P. Rajendran, G. Mathew, and B. John, Electron spin resonance dating of fault gouge from Desamangalam, Kerala: evidence for Quaternary movement in Palghat gap shear zone. Proc. Indian Acad. Sci., Earth Planet. Sci. vol. 111, pp. 103-113, 2002.

[24] GSI, Seismotectonic Atlas of India and its Environs. Geol. Surv. India Spec. Publ., no.59, 2000.

[25] Y. Singh, B. John, G.P. Ganapathy, A. George, S. Harisanth, K.S. Divyalakshmi, S. Kesavan, Geomorphic observations from southwestern terminus of Palghat Gap, South India and their tectonic implications. J. of Earth System Science, vol. 125, No. 4, June 2016, pp. 821-839.

[26] E. Praseeda, B. John, C. Srinivasan, Y. Singh, K.S. Divyalakshmi, and P. Samui, Thenmala fault system, southern India: implication to Neotectonics. Journal of Geological Society India, vol. 86 pp. 391398, 2015.

[27] U. Chandra, Earthquakes of peninsular India, a seismotectonic study, Bull Seism Soc Am, vol. 65, pp. 1387-1413, 1977.

[28] R.B. Rao and P.S. Rao, Historical seismicity of peninsular India, Bull Seism Soc Am, vol. 74, pp. 2519-2533,1984.
[29] B.V. Rao and B.V.S. Murty, Earthquakes and tectonics in peninsular India. J Ind Geophys Union, vol. 7, pp. 1-8, 1970.

[30] C. P. Rajendran, and K. Rajendran, Low- moderate seismicity in the vicinity of Palghat gap, South India and its implications, Current Science, vol.70, pp. 304-307, 1996.

[31] C.P. Rajendran, B. John, K. Sreekumari, and K. Rajendran, Reassessing the earthquake hazard in Kerala based on historical and current seismicity. J. Geol Soc. India. vol. 73, pp. 785-802, 2009.

[32] H. N. Singh, V. Raghavan, and A. K. Varma, Investigation of Idukki earthquake sequence of 7 th -8 th June 1988. Jour. Geol. Soc. India, v.34, pp.133-146,1989.

[33] S.N. Bhattacharya and R.S. Dattatrayam, Earthquake sequence in Kerala during December 2000 and January 2001. Current Science, vol. 82, pp. 1275-1278, 2002.

[34] D.C. Mishra, A.P. Singh and M.B.S.V. Rao, Idukki earthquake and the associated tectonics from Gravity study, J. Geol. Soc. India, vol. 34. pp.147-151, 1989.

[35] B.K. Rastogi, R.K. Chandra, and C.S.P. Sarma, Investigations of June 7, 1988 earthquake of magnitude 4.5 near Idukki Dam in southern India. Pageoph, vol.145, pp.109-122, 1995.

[36] K. Rajendran and C.P. Rajendran, A report on the December 2, 1994 Earthquake. Technical Report, Centre for Earth Science Studies, 34p, 1995.

[37] B. John, Characteristics of near surface crustal deformation associated with shield seismicity: two examples from peninsular India, Unpublished PhD thesis, 2003.

[38] K. Rajendran, P. Talwani, and H.K., Gupta, State of stress in the Indian subcontinent: a review, Current Science, vol. 62, pp. 86-93, 1992.

[39] T. N. Gowd, S.V. Srirama Rao, and K.B. Chary, Stress field and seismicity in the Indian shield: effects of the collision between India and Eurasia. Pure and Applied Geophysics, vol. 146, pp. 503-531, 1996.

[40] P. Mandal, Intraplate stress distribution induced by topography and crustal density heterogeneities beneath south Indian shield, India, Tectonophysics, vol. 302, pp. 159-172, 1999.

[41] P. Bettinelli, J.-P. Avouac, M. Flouzat, F. Jouanne, L. Bollinger, P. Willis, and G. R. Chitrakar, Plate motion of India and interseismic strain in the Nepal Himalaya from GPS and DORIS measurements, J. Geod., vol. 80, pp. 567-589, 2006.

[42] P. Banerjee, R. Burgmann, B. Nagarajan, and E. Apel, Intraplate deformation of the Indian subcontinent, Geophys. Res. Lett., 35, L18301, doi:10.1029/2008GL035468, 2008. 